\title{
A sense-able microRNA
}

\author{
Amy E. Pasquinelli \\ Division of Biology, University of California at San Diego, La Jolla, California 92093, USA
}

In this issue of Genes \& Development, Drexel and colleagues (pp. 2042-2047) present a beautiful example of how microRNAs (miRNAs) can regulate tissue-specific gene expression in a biologically relevant setting. They found that miR-791 is expressed in only three types of carbon dioxide $\left(\mathrm{CO}_{2}\right)$-sensing neurons in Caenorhabditis elegans, and its primary function there seems to be repression of two target genes that interfere with the behavioral response to $\mathrm{CO}_{2}$. Interestingly, these two targets are broadly expressed across other tissues. Thus, restricted miRNA expression can lead to target repression in select tissues to promote distinct cellular physiologies.

Virtually all cells in a multicellular organism possess the entire genetic code for the organism. However, each cell type expresses only a subset of these genes, allowing different tissues to develop distinct morphologies and physiologies. One way to establish unique gene expression domains is to control activation at the transcriptional level. The decision to turn a gene on or off or tune it to the spectrum in between usually involves a complex assembly of transcription factors and chromatin modifiers that ultimately regulate the ability of a gene to be transcribed into the messenger RNA (mRNA) that will encode the gene product. Alternatively, the mRNA itself can be the target of regulation at the post-transcriptional level. MicroRNAs (miRNAs) bind specific target mRNAs through base-pairing interactions and repress their translation and stability (Pasquinelli 2012). Thus, genes with broad transcriptional domains can be selectively regulated in certain tissues depending on the presence of a targeting miRNA.

The expression pattern of a miRNA can provide important clues toward its function. For example, temporal control of the first discovered miRNAs, lin-4 and let-7, enables them to repress key targets in the developmental timing pathway in Caenorhabditis elegans (Bartel 2009). Thus, a potential function for C. elegans miR-791 was revealed when Drexel et al. (2016) observed that its expression is restricted to three pairs of neurons involved in sensing carbon dioxide $\left(\mathrm{CO}_{2}\right)$ levels (Fig. 1). Normally, high $\mathrm{CO}_{2}$ levels signal an approaching predator, and

[Keywords: miRNAs; cell identity; C. elegans; carbon dioxide] Corresponding author: apasquinelli@ucsd.edu

Article is online at http://www.genesdev.org/cgi/doi/10.1101/gad.290023. 116. worms respond by moving in the opposite direction (Bretscher et al. 2008; Hallem and Sternberg 2008). This specific behavior was found to depend on miR-791, as deletion mutants have a muted response even though they exhibit no obvious defects in neuronal development or sensing another gas (Drexel et al. 2016). These results suggested that miR-791 activity is dedicated to the regulation of genes that interfere with $\mathrm{CO}_{2}$ sensation and possibly the avoidance response to it.

Since miRNAs use limited sequence complementarity to recognize their targets, it can be difficult to identify genes directly regulated by a particular miRNA (Pasquinelli 2012). However, a daunting list of predicted targets can be filtered by focusing on genes that might be relevant to a particular pathway. With the knowledge that miR791 likely regulates genes involved in neuronal signaling, two candidates rose to the top of the target list: AKAP-1 (A kinase anchor protein 1), which acts in subcellular signaling pathways, and CAH-3 (carbonic anhydrase 3), which metabolizes $\mathrm{CO}_{2}$. Indeed, Drexel et al. (2016) demonstrated that akap-1 and cah-3 are the physiologically relevant direct targets of miR-791 in the $\mathrm{CO}_{2}$-sensing neurons. Remarkably, though, these genes are broadly expressed in worms and seem to function in various pathways (Maeda et al. 2001; Benner et al. 2011). Thus, repression of akap-1 and cah-3 is limited to the miR791-expressing neurons to enable a complex sensory behavior (Fig. 1).

In addition to providing an elegant new example of a miRNA regulatory pathway, the study by Drexel et al. (2016) also puts forth two broader implications for the field. First, miRNAs with identical $5^{\prime}$ end sequences comprise families and have been proposed to target the same genes (Bartel 2009). While this may be true in some instances, a role in $\mathrm{CO}_{2}$ sensing was not detected for miR-790, which is identical to miR-791 at positions 210 and is expressed in the same neurons (Drexel et al. 2016). Furthermore, loss of miR-791 alone resulted in misregulation of the akap-1 and cah-3 targets and consequent defective avoidance behavior. Thus, in this biological context, the miR-790/791 family members are not redundant. This in vivo example lends credence to recent

(C) 2016 Pasquinelli This article is distributed exclusively by Cold Spring Harbor Laboratory Press for the first six months after the full-issue publication date (see http://genesdev.cshlp.org/site/misc/terms.xhtml). After six months, it is available under a Creative Commons License (Attribution-NonCommercial 4.0 International), as described at http:// creativecommons.org/licenses/by-nc/4.0/. 


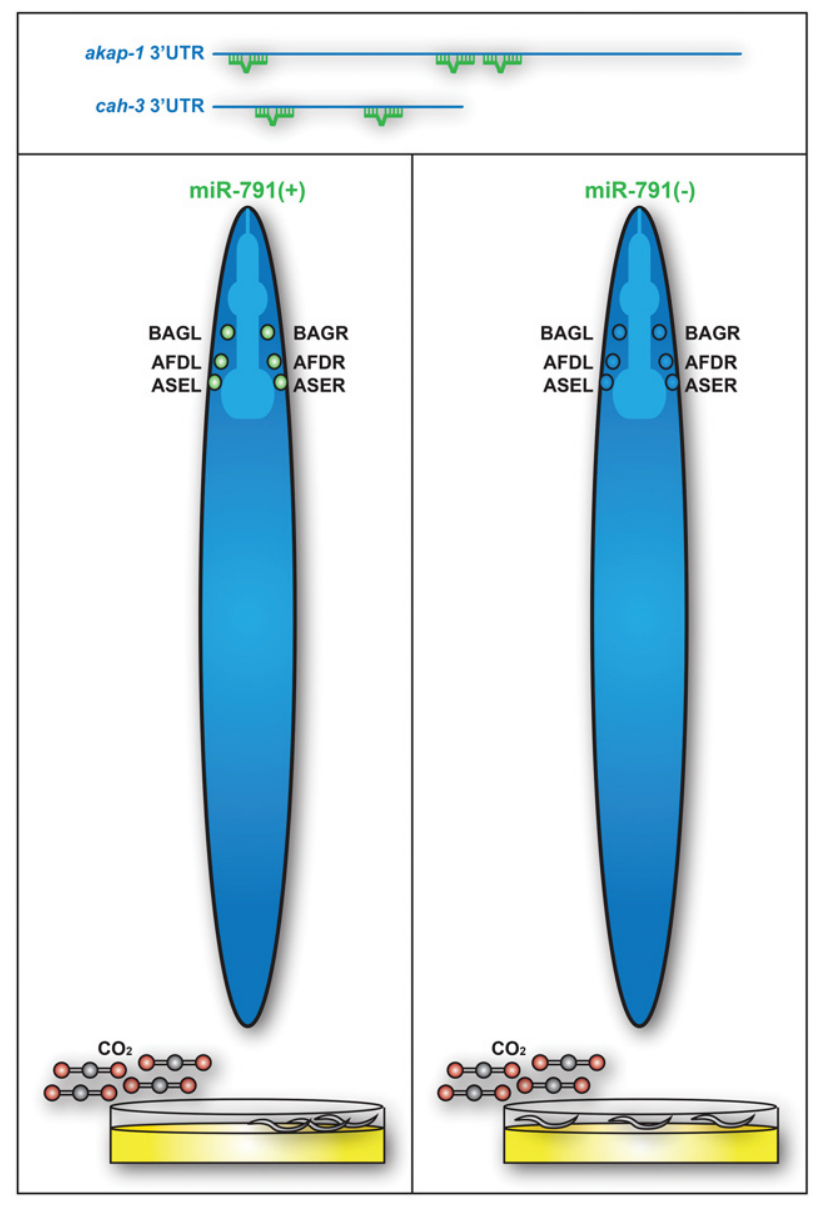

Figure 1. Restricted expression of miR-791 (green) in three sets of $\mathrm{CO}_{2}$-sensing neurons results in tissue-specific repression of the target genes akap-1 (A kinase anchor protein 1) and cah-3 (carbonic anhydrase 3) (blue) through several complementary sequences in their $3^{\prime}$ untranslated regions (UTRs). This regulation allows worms to avoid $\mathrm{CO}_{2}(l e f t)$, and the behavior is lost in its absence (right).

biochemical studies that have shown specific target-binding activity by distinct miRNA family members (Moore et al. 2015; Broughton et al. 2016). The second implication of this study is that a single miRNA, even a poorly conserved one, can have a function essential to animal survival in the wild. Previously, a broad screen for miRNA function indicated that deletion of individual miRNA genes results in no obvious phenotypes, except in rare cases (Miska et al. 2007). A current perception is that many miRNAs act redundantly or combinatorially to sculpt gene expression, buffering the loss of individual miRNAs (Miska et al. 2007; Bartel 2009). The study by Drexel et al. (2016) now provides a compelling demonstration that a single miRNA can have a biologically relevant function that may be apparent only in certain contexts. Given the lesson of miR-791, perhaps the idea that miRNAs exert largely redundant fine-tuning functions merits reconsideration.

\section{Acknowledgments}

I thank members of the Pasquinelli laboratory for critical reading of the manuscript. Research in the Pasquinelli laboratory is supported by a grant from the National Institutes of Health (GM071654).

\section{References}

Bartel DP. 2009. MicroRNAs: target recognition and regulatory functions. Cell 136: 215-233.

Benner J, Daniel H, Spanier B. 2011. A glutathione peroxidase, intracellular peptidases and the TOR complexes regulate peptide transporter PEPT-1 in C. elegans. PLoS One 6: e25624.

Bretscher AJ, Busch KE, de Bono M. 2008. A carbon dioxide avoidance behavior is integrated with responses to ambient oxygen and food in Caenorhabditis elegans. Proc Natl Acad Sci 105: 8044-8049.

Broughton JP, Lovci MT, Huang JL, Yeo GW, Pasquinelli AE. 2016. Pairing beyond the seed supports microRNA targeting specificity. Mol Cell 64: 1-14.

Drexel T, Mahofsky K, Latham R, Zimmer M, Cochella L. 2016. Neuron-type-specific miRNA represses two broadly expressed genes to modulate an avoidance behavior in C. elegans. Genes Dev doi: 10.1101/gad.287904.116.

Hallem EA, Sternberg PW. 2008. Acute carbon dioxide avoidance in Caenorhabditis elegans. Proc Natl Acad Sci 105: 80388043.

Maeda I, Kohara Y, Yamamoto M, Sugimoto A. 2001. Large-scale analysis of gene function in Caenorhabditis elegans by highthroughput RNAi. Curr Biol 11: 171-176.

Miska EA, Alvarez-Saavedra E, Abbott AL, Lau NC, Hellman AB, McGonagle SM, Bartel DP, Ambros VR, Horvitz HR. 2007. Most Caenorhabditis elegans microRNAs are individually not essential for development or viability. PLoS Genet 3: e215.

Moore MJ, Scheel TK, Luna JM, Park CY, Fak JJ, Nishiuchi E, Rice CM, Darnell RB. 2015. miRNA-target chimeras reveal miRNA 3 '-end pairing as a major determinant of Argonaute target specificity. Nat Commun 6: 8864.

Pasquinelli AE. 2012. MicroRNAs and their targets: recognition, regulation and an emerging reciprocal relationship. Nat ReV Genet 13: 271-282. 


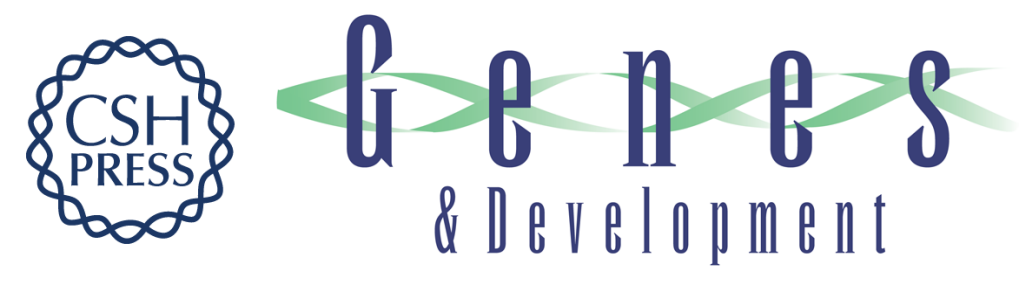

\section{A sense-able microRNA}

Amy E. Pasquinelli

Genes Dev. 2016, 30:

Access the most recent version at doi:10.1101/gad.290023.116

Related Content Neuron type-specific miRNA represses two broadly expressed genes to modulate an avoidance behavior in C. elegans

Tanja Drexel, Katharina Mahofsky, Richard Latham, et al.

Genes Dev. September , 2016 30: 2042-2047

References This article cites 10 articles, 3 of which can be accessed free at:

http://genesdev.cshlp.org/content/30/18/2019.full.html\#ref-list-1

Articles cited in:

http://genesdev.cshlp.org/content/30/18/2019.full.html\#related-urls

Creative This article is distributed exclusively by Cold Spring Harbor Laboratory Press for the first Commons License six months after the full-issue publication date (see http://genesdev.cshlp.org/site/misc/terms.xhtml). After six months, it is available under a Creative Commons License (Attribution-NonCommercial 4.0 International), as described at http://creativecommons.org/licenses/by-nc/4.0/.

Email Alerting Receive free email alerts when new articles cite this article - sign up in the box at the top Service right corner of the article or click here.

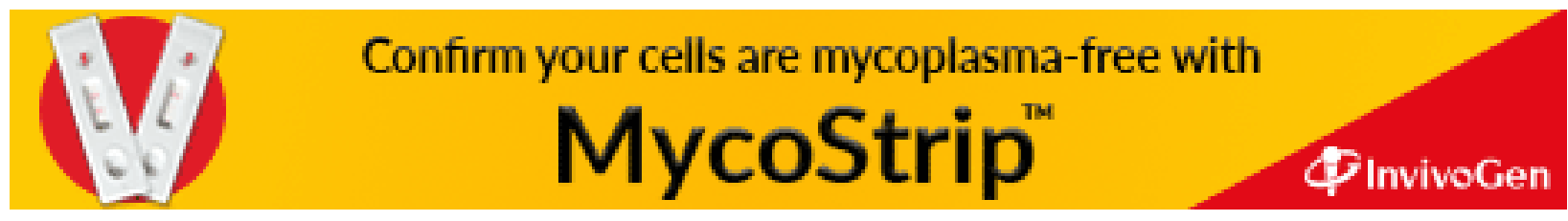

